\title{
Clinical impact of mutation fraction in epidermal growth factor receptor mutation positive NSCLC patients
}

Petra Martin ${ }^{1}$, Carolyn J Shiau ${ }^{1}$, Maria Pasic ${ }^{1}$, Ming Tsao ${ }^{1}$, Suzanne Kamel-Reid ${ }^{1}$, Stephanie Lin ${ }^{1}$, Roxana Tudor ${ }^{1}$, Susanna Cheng ${ }^{2}$, Brian Higgins ${ }^{3}$, Ronald Burkes ${ }^{4}$, Matilda Ng${ }^{5}$, Saroosh Arif ${ }^{6}$, Peter M Ellis ${ }^{7}$, Stacy Hubay ${ }^{8}$, Sara Kuruvilla ${ }^{9}$, Scott A Laurie ${ }^{10}$, Jing Li ${ }^{11}$, David Hwang ${ }^{12}$, Anthea Lau ${ }^{1}$, Frances A Shepherd ${ }^{1}$, Lisa W Le ${ }^{1}$ and Natasha B Leighl ${ }^{\star}, 1$

${ }^{1}$ Division of Medical Oncology, Princess Margaret Cancer Centre/University Health Network, 5-105 610 University Avenue, Toronto, Ontario, Canada M5G 2M9; ${ }^{2}$ Odette Cancer Centre, Toronto, Ontario, Canada; ${ }^{3}$ Credit Valley Hospital, Mississauga, Ontario, Canada; ${ }^{4}$ Mount Sinai Hospital, Toronto, Ontario, Canada; ${ }^{5}$ Mackenzie Health Centre, Richmond Hill, Ontario, Canada; ${ }^{6}$ Mississauga Hospital, Toronto, Ontario, Canada; ${ }^{7}$ Juravinski Cancer Centre, Hamilton, Ontario, Canada; ${ }^{8}$ Grand River Regional Cancer Centre, Kitchener, Ontario, Canada; ${ }^{9}$ London Regional Cancer Centre, London, Ontario, Canada; ${ }^{10}$ The Ottawa Hospital Cancer Centre, Ottawa, Ontario, Canada; ${ }^{11}$ Toronto East General Hospital, Toronto, Ontario, Canada and ${ }^{12}$ Toronto General Hospital, Toronto, Ontario, Canada

Background: We examined clinical outcomes in a population-based cohort of EGFR mutant advanced NSCLC patients, exploring the potential role of factors including tumour EGFR mutation fraction and cellularity in predicting outcomes.

Methods: A cohort of patients with EGFR mutant advanced NSCLC was identified (N=293); clinical outcomes, pathologic and treatment details were collected. Tumour response was determined from radiology and clinical notes. Association between demographic and pathologic variables EGFR TKI response, time to treatment failure (TTF) and overall survival (OS) was examined using logistic regression and proportional hazards regression. EGFR TKI response rates were summarised by percent mutation fraction to explore their association.

Results: Higher mutation fraction was associated with greater EGFR TKI response rate (odds ratio $1.58,95 \% \mathrm{Cl}=1.21-2.07$, $P=0.0008$ ), longer TTF (hazard ratio $0.80,95 \% \mathrm{Cl}=0.68-0.92, P=0.003$ ) and better OS (hazard ratio $0.81,95 \% \mathrm{Cl}=0.67-0.99$, $P=0.04)$. However, even in patients with $\leqslant 5 \%$ mutation fraction, response rate was $34 \%$. Females had longer TTF $(P=0.02)$.

Conclusions: EGFR mutation fraction in tumour samples was significantly associated with response, TTF and OS. Despite this, no lower level of mutation fraction was detected for which EGFR TKI should be withheld in those with activating EGFR mutations.

Epidermal growth factor receptor (EGFR) is one of the four closely related subgroup members of the human epidermal growth factor receptor (HER)-family (EGFR [HER1/ErbB1], HER2 [ErbB2], HER3 [ErbB3] and HER4 [ErbB4]; Cadranel et al, 2013). The most common activating mutations involve short deletions in the tyrosine kinase (TK) domain in exon 19 (E746_A750) and point mutations in exon 21 (L858R) of the EGFR gene. These mutations result in constitutive activation of the TK domain and downstream pathway signalling activation, resulting in increased cell proliferation, decreased apoptosis and metastasis (Pao et al, 2005; Jackman et al, 2010). Multiple phase III trials in advanced non-small cell lung cancer (NSCLC) patients with EGFR-activating mutations

*Correspondence: Dr NB Leighl; E-mail: natasha.leighl@uhn.ca

Received 21 January 2015; revised 4 January 2016; accepted 10 January 2016; published online 18 February 2016

(c) 2016 Cancer Research UK. All rights reserved 0007 - 0920/16 
have shown EGFR tyrosine kinase inhibitors (TKIs) have superior response, quality of life and progression-free survival compared with first-line platinum-based chemotherapy (Mok et al, 2009; Rosell et al, 2009; Maemondo et al, 2010; Mitsudomi et al, 2010; Zhou et al, 2011; Rosell et al, 2012; Yang et al, 2012; Inoue et al, 2013). The median time to progression (TTP) with EGFR TKIs in EGFR mutation-positive NSCLC is 9 to 13 months (Jackman et al, 2010; Cadranel et al, 2013). Secondary resistance often arises with the emergence of resistance mutations (Kobayashi et al, 2005; Pao et al, 2005; Sequist et al, 2011). An additional ten percent of patients present with primary resistance to EGFR TKIs at first evaluation despite the presence of EGFR mutant cells in their tumour (Cadranel et al, 2013). Primary resistance is likely a multifactorial process resulting from numerous genetic alterations (Ellis and Hicklin, 2009; Hammerman et al, 2009). Purported mechanisms of primary resistance include insertion mutations in exon 20 of the EGFR or HER2 gene, loss of PTEN, BRAF and KRAS mutations; and increased levels of MAPK, IGFR2, BCL-2 and MET amplification (Sequist et al, 2008; Ellis and Hicklin, 2009; Hammerman et al, 2009; Turke et al, 2010). It is not possible to predict which patients with activating mutations will not respond to EGFR TKI therapy, and the mechanism of primary resistance is poorly understood. This suggests that other factors in addition to EGFR mutation status may determine response to EGFR TKIs.

EGFR mutations are assessed with polymerase chain reaction (PCR) and have a $1-5 \%$ detection sensitivity (lowest percent reliably detectable (Gocke et al, 2000; Milbury et al, 2009; Kamel-Reid et al, 2012; Shiau et al, 2014). Unlike HER2 amplification in breast and gastric cancer and $A L K$ rearranged NSCLC where quantitative cut-offs have been established (Hirsch et al, 2002; Heinmoller et al, 2003; Camidge et al, 2010, 2013), it is unknown whether the level of EGFR mutation fraction affects response to EGFR TKIs. Previous investigation from our institution has shown that tumour cellularity was significantly associated with EGFR test success in NSCLC histology and cytology samples (Shiau et al, 2014). In another study, 75\% of NSCLC samples with poor cellularity, but considered to be representative of tumour, were successfully tested with an EGFR mutation prevalence of $9 \%$ (Leary et al, 2012). The recent CAP/IASLC/AMP Molecular Testing Guideline for lung cancer highlights that an ideal test should be able to detect mutations in samples with tumour cellularity as low as $10 \%$ (Lindeman et al, 2013). The guidelines also recognise that while analytic sensitivity is important for smaller samples, ultrasensitive molecular assays may carry risks of false positive results. However, the impact of sample quality, including tumour cellularity, and EGFR mutation fraction on clinical outcome with EGFR TKI is unknown.

In this study, we describe clinical outcomes with EGFR TKI therapy, including response rate (RR), time to treatment failure (TTF) and overall survival (OS), in a population-based cohort of advanced EGFR mutation-positive NSCLC patients, and explore potential predictors of outcome including histopathologic correlates of tumour sample, EGFR mutation fraction, cellularity, sample and mutation type, and demographic variables. We also explore the relationship between different levels of mutation fraction and outcome, to identify a threshold associated with EGFR TKI response.

\section{MATERIALS AND METHODS}

The study protocol was approved by the research ethics boards of the eleven participating centres, along with data-sharing agreements. From March 2010 to March 2012, EGFR testing in the province of Ontario, Canada was conducted at a single centre (University Health Network, Toronto, Canada; UHN). The choice of 2010 to 2012 was due to the centralisation of EGFR testing to the UHN. Patients with EGFR mutation-positive samples were identified at each centre, and evaluated for EGFR mutation fraction. Standard protocol for EGFR mutation testing included an initial review of the haematoxylin- and eosin (HE)-stained section, prepared at the same time as unstained sections for DNA isolation, from the submitted tumour block. The slides and reports were reviewed by a pulmonary pathologist or cytopathologist. Samplerelated parameters available in original reports or as assessed by pathologists were recorded. For histology samples, pathologists marked the tumour areas on the HE section to guide macrodissection by the molecular laboratory technologists.

EGFR mutation fraction was defined as the ratio between mutant EGFR and wild-type alleles in the macrodissected sample, but does not control for potential normal cell DNA contamination. Tumour cellularity was defined as the percentage of epithelial NSCLC tumour cells to all nucleated cells within the test sample (Shiau et al, 2014), and was performed on the same macrodissected sample, which allowed analysis to be performed in the same region. Mutation testing was conducted using fragment analysis (exon-19 deletions) and restriction fragment length polymorphism (exon-21 L858R) methods (Shiau et al, 2014). The same method of detection for EGFR exon 19 deletions and the L858R exon 21 mutation was used throughout the entire time period. The detection limit has been established at 1 to $5 \%$ by serial dilutions of relevant cell line DNA (Shiau et al, 2014). A reagent control, negative control and two positive controls were included with each run. Final test results were reported as (1) positive for exon-19 deletion, (2) positive for exon-21 L858R mutation or (3) negative for exon-19 deletion or exon-21 L858R mutation.

Clinical data were collected including demographic and tumour sample information, response to EGFR TKI, TTF and OS. Response assessment after EGFR TKI therapy was based on the best response reported in radiology and/or clinical reports. Response was defined as evidence of tumour regression, stable disease if there was no change in tumour size, mixed response if there was regression in some tumours but progression in others with continuation of EGFR TKI therapy and progressive disease in the case of tumour growth. TTF was calculated from the start of EGFR TKI treatment until the EGFR TKI treatment stoppage date or the date of death if the patient died on treatment. Patients were censored at last follow-up date if still on treatment or if lost to follow-up. OS was calculated from the start of EGFR TKI treatment until the date of death or censored at the last follow-up date.

Statistical analysis. Cox proportional hazard models (TTF, OS) and proportional odds logistic regression (tumour response) were used to assess the association between clinical outcomes and factors including EGFR mutation fraction, tumour sample cellularity, age, sex, smoking status, EGFR mutation type (exon 19 or 21), sample biopsy site (primary or metastatic) and EGFR TKI in the first-line $v s$ second-line setting. Smoking status was ascertained from the medical notes recorded by the medical oncologist at the patient's first visit. Mutation fraction was analysed as a continuous variable in Cox regression and logistic regression analyses. The distribution of mutation fraction was right skewed; therefore, we performed a natural log transformation to achieve approximate normality. Cellularity was considered as a confounding factor, and it was included in all multivariable analyses to correct for this potential impact on biomarkers such as mutation fraction. Cellularity was dichotomised at its median (50\%) as high vs low. All factors with $P<0.25$ in the univariable analysis were included in a stepwise variable selection procedure for the multivariable analysis, and those with $P<0.10$ were included in the final multivariable analysis. Hazard ratio (HR) and odds ratio (OR) with their 95\% confidence interval (CI) were reported. 


\section{RESULTS}

Patient and tumour sample characteristics. A total of 293 patients with activating EGFR mutations were identified at the 11 participating centres (Table 1). Of these, 253 received EGFR TKI treatment, $79 \%(n=200)$ as first-line treatment for NSCLC, $21 \%(n=53)$ as second-line treatment. Forty patients $(14 \%) \mathrm{did}$ not receive an EGFR TKI. The median age at diagnosis of metastatic disease was 65.2 years (range 26.2-95.5) in the cohort, with a predominance of females (72\%). Most patients were never smokers (59\%), 59\% were Caucasian and 38\% were Asian. The median follow-up time from the date of metastatic diagnosis was 24.4 months (range 0.03-69.9 months) and the median follow-up time from the date of EGFR TKI treatment initiation was 18.8 months (range 0-43.7 months).

The sample type submitted for EGFR testing was evenly split among resected samples (32\%), fine-needle aspirate (FNA) or pleural fluid cytology samples (30\%), and core lung biopsies (38\%). Most (61\%) had the primary sampled and submitted for EGFR

\section{Table 1. Demographics and patient characteristics (TKI} treated, $N=253$ )

\begin{tabular}{|c|c|}
\hline Characteristics & Number of patients $(\%$ \\
\hline \multicolumn{2}{|l|}{ Age } \\
\hline Median (range) & 65.2 years $(26.2-95.5)$ \\
\hline \multicolumn{2}{|l|}{ Sex } \\
\hline Female & $183(72 \%)$ \\
\hline Male & $70(28 \%)$ \\
\hline \multicolumn{2}{|l|}{ Ethnicity } \\
\hline White & $173(59 \%)$ \\
\hline Asian & $110(38 \%)$ \\
\hline Black & $10(3 \%)$ \\
\hline Median tumour sample cellularity $(n=238)$ & $50.0 \%$ (range 1.0-98.0\%) \\
\hline Median EGFR mutation frequency $(n=246)$ & $29.7 \%$ (range $0.4-96.2 \%$ ) \\
\hline \multicolumn{2}{|l|}{ EGFR } \\
\hline Exon 19 & $134(53 \%)$ \\
\hline Exon 21 & $119(47 \%)$ \\
\hline \multicolumn{2}{|l|}{ Smoking history } \\
\hline Current & $16(7 \%)$ \\
\hline Former & $80(34 \%)$ \\
\hline Non-smoker & $140(59 \%)$ \\
\hline Unknown & 17 \\
\hline \multicolumn{2}{|l|}{ Best response to EGFR TKI } \\
\hline Response & $141(62 \%)$ \\
\hline Stable/mixed & $58(25 \%)$ \\
\hline Progression & 30 (13\%) \\
\hline No assessment/unknown & 24 \\
\hline \multicolumn{2}{|l|}{ Sample tested } \\
\hline Resected sample & $81(32 \%)$ \\
\hline Cytology sample & 76 (30\%) \\
\hline Core biopsy & $96(38 \%)$ \\
\hline \multicolumn{2}{|l|}{ Biopsy site } \\
\hline Primary & $154(61 \%)$ \\
\hline Metastases & $99(39 \%)$ \\
\hline \multicolumn{2}{|c|}{ Received subsequent treatment after EGFR-TKI } \\
\hline Second-line chemotherapy & $50(20 \%)$ \\
\hline Platinum-based doublet & 38 (15\%) \\
\hline $\begin{array}{l}\text { Mean number of cycles of second-line } \\
\text { chemotherapy }\end{array}$ & 4 cycles \\
\hline Third line chemotherapy & $15(6 \%)$ \\
\hline Fourth line chemotherapy & $1(0.3 \%)$ \\
\hline Another EGFR TKI or TKI trial & $15(6 \%)$ \\
\hline Lost to follow-up & 27 (11\%) \\
\hline
\end{tabular}

testing. Half (53\%) had an exon 19 mutation. The median cellularity of submitted samples was 50.0\% (range 1.0-98.0\%). The median mutation fraction was $27.2 \%$ (range $0.4-96.2 \%$, $25-75 \%$ interquartile range $10-50 \%)$.

Clinical outcome of the EGFR mutation-positive patients treated with EGFR TKIs - Factors associated with response, TTF and OS

EGFR TKI response. The majority of patients (62\%) had a response to EGFR TKIs (measured as any tumour regression); $25 \%$ of patients had stable disease or mixed response; and $13 \%$ demonstrated progression of disease on therapy. In multivariable analysis, mutation fraction was significantly associated with response (OR 1.58, 95\% $\mathrm{CI}=1.21-2.07, P=0.0008$ ), even after correcting for the confounding effect of tumour cellularity (Table 2). However, even with $\leqslant 5 \%$ mutation fraction, we saw a $34 \%$ response rate. Younger age was significant on univariable analysis (OR 0.75 per 10 years, $P=0.01$ ), but it was not significant on the multivariate analysis $(P=0.06$, Table 2$)$.

Time to treatment failure. A total of 165 patients (64\%) had experienced treatment failure at the time of analysis. The median TTF on EGFR TKI was 13.2 months (95\% CI = 10.7-14.9 months), Figure 1. In the subgroup of patients who had response, TTF was 17.3 months (95\% CI $=15.0-21.0$ months) vs 9.2 months in those with stable disease/mixed response (95\% CI $=7.5-14.7$ months) and 2.3 months in the subgroup without response $(95 \% \mathrm{CI}=1.9$ NA or upper limit not reached). In multivariable Cox analysis, after correcting for tumour cellularity, higher mutation fraction (HR 0.80, 95\% CI =0.68-0.92, $P=0.003$ ) and female sex (HR 0.66, $P=0.02$ ) were significantly associated with a longer TTF (Table 3 ).

Overall survival from EGFR TKI initiation. One hundred and five patients (42\%) had died at the time of analysis. The 1-year and

Table 2. Predictors associated with responses to EGFR-TKI treatment

\begin{tabular}{|l|c|c|c|c|c|c|}
\hline \multicolumn{2}{|c|}{ Best response (response vs mixed/stable vs progression) } \\
\hline & \multicolumn{3}{|c|}{ Univariable } & \multicolumn{3}{c|}{ Multivariable } \\
\cline { 2 - 7 } & $\begin{array}{l}\text { Odds } \\
\text { ratio }\end{array}$ & $95 \%$ CI & $P$-value & $\begin{array}{c}\text { Odds } \\
\text { ratio }\end{array}$ & $95 \%$ Cl & P-value \\
\hline $\begin{array}{l}\text { EGFR } \\
\text { mutation } \\
\text { frequency, in } \\
\text { log scale }\end{array}$ & 1.60 & $1.25-2.06$ & 0.0002 & 1.58 & $1.21-2.07$ & 0.0008 \\
\hline $\begin{array}{l}\text { Tumour } \\
\text { cellularity, } \\
\text { high vs low }\end{array}$ & 0.85 & $0.50-1.44$ & 0.54 & 0.63 & $0.36-1.12$ & 0.12 \\
\hline $\begin{array}{l}\text { Age, per 10 } \\
\text { years }\end{array}$ & 0.75 & $0.60-0.94$ & 0.01 & 0.79 & $0.62-1.01$ & 0.06 \\
\hline $\begin{array}{l}\text { Sex, female } \\
\text { vs male }\end{array}$ & 1.11 & $0.62-2.00$ & 0.72 & & & \\
\hline $\begin{array}{l}\text { Smoking, } \\
\text { ever smoking } \\
\text { vs other }\end{array}$ & 0.61 & $0.35-1.06$ & 0.08 & & & \\
\hline $\begin{array}{l}\text { Mutation } \\
\text { type, exon 19 } \\
\text { vs exon 21 }\end{array}$ & 0.85 & $0.51-1.44$ & 0.55 & & & \\
\hline $\begin{array}{l}\text { Biopsy site, } \\
\text { primary vs } \\
\text { metastasis }\end{array}$ & 0.96 & $0.56-1.64$ & 0.89 & & & \\
\hline $\begin{array}{l}\text { EGFR TKI, } \\
\text { first line vs } \\
\text { second line }\end{array}$ & 0.92 & $0.49-1.76$ & 0.81 & & & \\
\hline $\begin{array}{l}\text { Abbreviations: Cl=confidence interval; } \\
\text { TKI=tyrosine kinase inhibitor. }\end{array}$ & EGFR=epidermal growth factor & receptor; \\
\hline
\end{tabular}




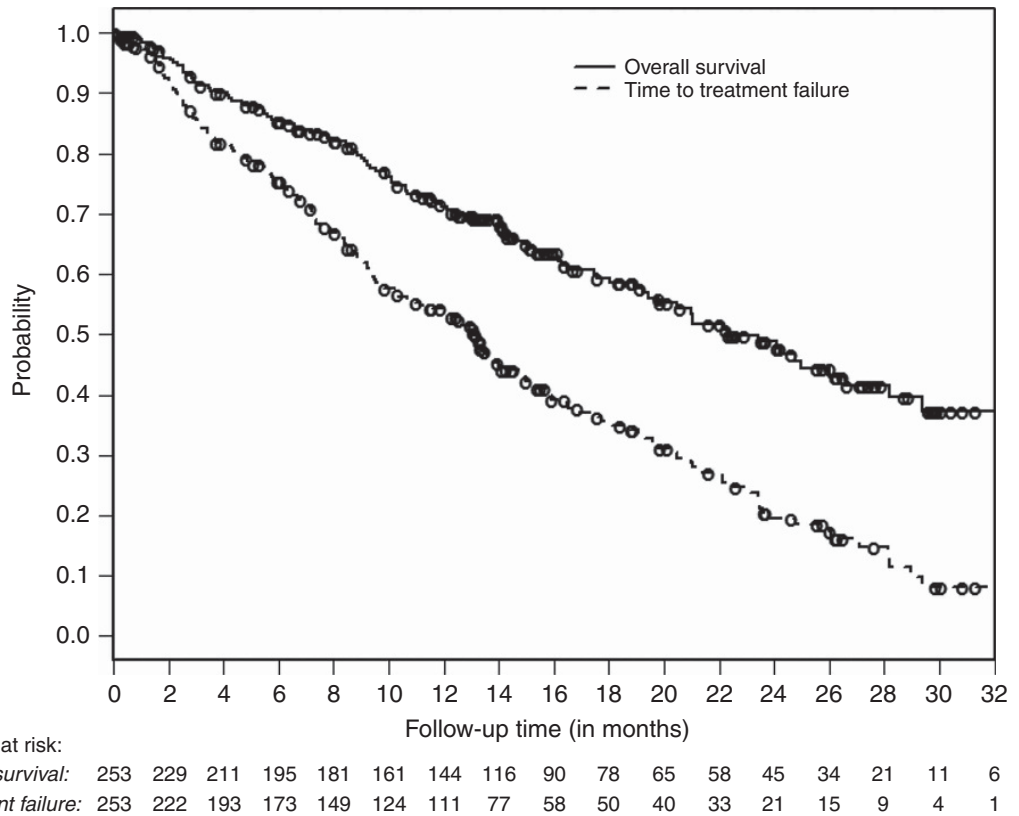

Figure 1. Time to treatment failure and overall survival in patients treated with EGFR-TKI.

Table 3. Predictors associated with time to treatment failure and overall survival

\begin{tabular}{|c|c|c|c|c|c|c|c|c|c|c|c|c|}
\hline \multicolumn{7}{|c|}{ Time to treatment failure } & \multicolumn{6}{|c|}{ Overall survival } \\
\hline & \multicolumn{3}{|c|}{ Univariable } & \multicolumn{3}{|c|}{ Multivariable } & \multicolumn{3}{|c|}{ Univariable } & \multicolumn{3}{|c|}{ Multivariable } \\
\hline & $\begin{array}{l}\text { Hazard } \\
\text { ratio }\end{array}$ & $95 \% \mathrm{Cl}$ & $P$-value & $\begin{array}{l}\text { Hazard } \\
\text { ratio }\end{array}$ & $95 \% \mathrm{Cl}$ & $P$-value & $\begin{array}{c}\text { Hazard } \\
\text { ratio }\end{array}$ & $95 \% \mathrm{Cl}$ & $P$-value & $\begin{array}{l}\text { Hazard } \\
\text { ratio }\end{array}$ & $95 \% \mathrm{Cl}$ & $P$-value \\
\hline $\begin{array}{l}\text { EGFR mutation } \\
\text { frequency, in log scale }\end{array}$ & 0.81 & $0.70-0.94$ & 0.005 & 0.80 & $0.68-0.92$ & 0.003 & 0.80 & $0.67-0.95$ & 0.01 & 0.81 & $0.67-0.99$ & 0.04 \\
\hline $\begin{array}{l}\text { Tumour cellularity, } \\
\text { high vs low }\end{array}$ & 0.89 & $0.64-1.22$ & 0.46 & 1.00 & $0.72-1.38$ & 0.99 & 1.31 & $0.89-1.96$ & 0.17 & 1.38 & $0.92-2.09$ & 0.12 \\
\hline Age, per 10 yrs & 1.08 & $0.95-1.23$ & 0.21 & & & & 1.23 & $1.04-1.45$ & 0.01 & 1.20 & $0.99-1.44$ & 0.06 \\
\hline Sex, female vs male & 0.7 & $0.51-0.98$ & 0.04 & 0.66 & $0.48-0.93$ & 0.02 & 0.77 & $0.51-1.17$ & 0.23 & & & \\
\hline $\begin{array}{l}\text { Smoking, ever smoking } \\
\text { vs others }\end{array}$ & 1.31 & $0.96-1.80$ & 0.09 & & & & 1.67 & $1.12-2.48$ & 0.01 & & & \\
\hline $\begin{array}{l}\text { Mutation type, exon } \\
19 \text { vs exon } 21\end{array}$ & 0.9 & $0.66-1.22$ & 0.49 & & & & 0.99 & $0.67-1.45$ & 0.95 & & & \\
\hline $\begin{array}{l}\text { Biopsy site, primary vs } \\
\text { metastases }\end{array}$ & 0.86 & $0.62-1.18$ & 0.34 & & & & 0.89 & $0.60-1.33$ & 0.57 & & & \\
\hline $\begin{array}{l}\text { EGFR TKI, first line vs } \\
\text { second line }\end{array}$ & 0.93 & $0.65-1.33$ & 0.67 & & & & 1.04 & $0.66-1.66$ & 0.86 & & & \\
\hline
\end{tabular}

2-year survival rates in the cohort were $71.2 \%(95 \% \mathrm{CI}=65.5 \%$ $77.4 \%)$ and $48.9 \% \quad(95 \% \quad \mathrm{CI}=41.6 \%-57.4 \%)$, respectively (Figure 1). Median survival for patients who received EGFR TKI in the first-line setting was 21.0 months (95\% CI $=18.9-28.2$ months) from the start of therapy, and 26.0 months $(95 \%$ $\mathrm{CI}=12.5-\mathrm{NA} ; \quad P=0.86$ ) for those receiving EGFR TKI as second-line therapy. In multivariable analysis, higher mutation fraction was associated with longer OS (HR 0.81, 95\% CI $=0.67-$ $0.99, P=0.04)$, after correcting for the effect of cellularity (Table 3). Increasing age was associated with shorter OS on the univariable analysis, but not on the multivariable Cox regression $(P=0.06)$.

Subsequent treatment following progression on EGFR TKI. Although approximately one-third of patients in the cohort remained on EGFR TKI, most (32\%) did not receive any additional systemic therapy after EGFR TKI failure. Twenty-one percent received subsequent therapy after progression on EGFR TKI therapy, most commonly ( $76 \%$ of cases) platinum-based doublet chemotherapy for a median of four cycles (range 1-6). Of these, 15 (30\%) had a response (defined as any tumour regression) to second-line treatment (first-line chemotherapy), another $40 \%$ had stable disease and 28\% progressive disease. Only 15 patients received third-line treatments. Median duration of third-line therapy was 3.5 cycles; two of 15 achieved response, six had stable disease and three progressed. Fifteen patients received a secondgeneration EGFR TKI or participated in a randomised trial of a second-generation EGFR TKI (NCIC Clinical Trials Group BR.26 dacomitinib vs placebo; NCT01000025).

EGFR mutation-positive patients not treated with EGFR TKI. Forty patients $(14 \%)$ in the cohort with EGFR mutations did not receive an EGFR TKI. The most common reasons for nontreatment were that patients were too unwell or had died before testing results and/or EGFR TKI funding approval. Other reasons included loss to follow-up and minimal disease burden on observation. Median survival in those untreated was 3.6 months $(95 \% \mathrm{CI}=2.4-\mathrm{NR})$. 


\section{DISCUSSION}

The introduction of EGFR TKI therapies and discovery of EGFR mutations in the last decade has significantly changed the approach to the treatment of NSCLC (Antonicelli et al, 2013; Cadranel et al, 2013). However, as many as 30 to $40 \%$ of patients with activating EGFR mutations do not have a major response to EGFR TKI therapy (Cadranel et al, 2013). This suggests that additional factors may influence EGFR signalling, including dysregulation of other genes and pathways. We assessed potential factors including EGFR mutation fraction and cellularity affecting clinical outcomes in patients with EGFR-activating mutations treated with EGFR-TKIs. In our study, there was an increase in response with increasing EGFR mutation fraction; however, response for those patients with $\leqslant 5 \%$ mutation fraction was still considerable, with $34 \%$ of patients experiencing tumour regression. Therefore any level of mutation fraction should be tested for an EGFR mutation, as long as it is within the reliable lower limit of detection of the EGFR testing method, and all patients with an activating mutation detected in their tumours should be offered an EGFR TKI. No EGFR mutation fraction cut-off level was identified at which it would be considered reasonable to withhold treatment. However clinicians should be mindful that lower mutation fraction levels may be associated with lesser response, shorter TTF and OS as demonstrated in this study. Variables associated with a longer TTF included increasing EGFR mutation fraction and female sex. Following multivariable analysis, factors associated with improved response and OS included increasing mutation fraction. Increasing age was associated with a poorer response and worse OS in univariate analysis, but was not significant following multivariable analysis. From our study, we found mutation fraction to be a useful measure which was associated with survival outcomes and is a parameter that can be used by clinical labs globally. However this measurement does have limitations, as it cannot rule out the potential for normal cell inclusion.

With the heterogeneous nature of cancer, it is reasonable to expect that not all cells within a tumour will have mutant EGFR alleles. EGFR mutation fraction may be a reflection of the proportion of EGFR TKI-sensitive cells in a tumour, but may be biased because of sampling or other issues, such as the presence of EGFR amplification. There is increasing evidence that intratumour heterogeneity (ITH), as defined by the 'presence of cell subpopulations harbouring distinct biologic properties', results in the emergence of resistant subclones and has a role in the resistance to therapies (Snuderl et al, 2011; Swanton, 2012). Intratumour heterogeneity has demonstrated spatial and temporal expression within a single lesion (Crockford et al, 2014). Intratumour heterogeneity has been demonstrated in a number of cancers including glioblastoma multiforme (GBM). Sottoriva et al (2013) collected spatially distinct tumour fragments from 11 GBM patients and identified copy number alterations in EGFR/ CDKN2A/Bp14ARF as early driver events, and aberrations in PDGFRA and PTEN as later events during cancer progression. Previous investigation in NSCLC patients with EGFR mutations identified tumours with heterogeneous populations of both EGFR mutated and non-mutated cancer cells resulting in reduced response to gefitinib (Taniguchi et al, 2008). Therefore, a putative alteration in EGFR mutation fraction numbers could be proposed to exist throughout the tumour. To demonstrate this, it would require sampling multiple sites of tumour tissue for EGFR mutation fraction. However, our data demonstrated that the response rate was $34 \%$ even in patients whose tumours contained $\leqslant 5 \%$ mutation fraction and so they too should be offered treatment with an EGFR-TKI. Therefore testing multiple tumour sites would be unlikely to affect the management decision to treat with an EGFR-TKI in patients with an activating EGFR mutation.
Tumours involving the colon, breast, brain and pancreas have an average of 33 to 66 genes that display subtle somatic mutations, resulting in altered protein products (Vogelstein et al, 2013). The majority of these mutations are single-base substitutions, and to a lesser extent deletions or insertions. In addition, gene amplification has been demonstrated to have a role in other cancers. For example, breast cancer patients with overexpression of HER2 amplification have shorter disease-free interval and poorer OS than patients whose cancer do not overexpress HER2 (Mayer, 2009). It has been proposed that the variation in survival outcomes seen in patients with EGFR-activating mutations may be a result of tumour heterogeneity (Shan et al, 2015). There is evidence that increased EGFR copy number is associated with better response to EGFRTKIs (Hirsch et al, 2002; Cappuzzo et al, 2005). A recent study assessing the concurrence of EGFR amplification and sensitizing mutations with survival outcomes from EGFR-TKI therapy identified that patients with EGFR gene amplification had a significantly longer PFS than those without (Shan et al, 2015). We did not assess EGFR amplification in our study; however, given this recent data, assessment of EGFR copy number and its association with EGFR mutation fraction and its effect on clinical outcome should be assessed in future studies.We now know that some mutations such as the T790M mutation, a rare exon 20 mutation, is associated with resistance to EGFR-TKIs ( $\mathrm{Yu}$ et al, 2014). At the time of our study, it was not common practice to test for mutations other than exon 19 and 21. Future investigation to assess for other mutations, including resistance mutations, and their association with EGFR mutation fraction would be interesting and may provide further insight into the clinical response that was seen with the different mutation fraction groups. In this study, we used fragment analysis and RFLP which was the available technology in our institution at the time to measure EGFR mutation status. Since then, there are many alternative platforms including real-time PCR and next-generation sequencing, which allow quantitative testing of multiple mutations. However, as tumours are heterogeneous, attaining a representative sample of tumour is an important consideration in all these techniques. Recently, platforms such as Sequined or Snapshot can assess for multiple genetic abnormalities (Korpanty and Leighl, 2012). In addition, platforms such as FoundationOne also incorporate the detection of gene rearrangement and changes in gene copy number (Korpanty and Leighl, 2012). Future work assessing the use of EGFR mutation fraction in EGFR mutation positive tumours should be assessed with alternative diagnostic platforms.

Median survival for patients treated with EGFR TKIs in the first-line setting in this community-based population was 21.0 months (95\% CI $=18.9-28.2$ months), similar to survival outcomes reported in clinical trials. It is interesting that the majority of patients $(80 \%)$ did not receive second-line chemotherapy after EGFR TKI progression. However, the majority (70\%) of those who did receive further therapy, had evidence of clinical benefit and a similar number of cycles as that which most patients receive firstline. Although our study did not collect data as to the reasons behind not pursuing further therapy after EGFR TKI failure, it is important for clinicians to educate patients that there is a role for second-line chemotherapy if performance status is adequate.

In our study, pre-treatment tumour cellularity was not associated with survival outcomes. Assessment of tumour cellularity change has been investigated in neoadjuvant studies. Radiological response to EGFR TKI treatment in NSCLC patients treated preoperatively with gefitinib for 28 days was related to loss of tumour cellularity and cell proliferation (Rajan et al, 2004; LaraGuerra et al, 2012). Reduction in tumour cellularity has also been noted with neoadjuvant chemotherapy in breast cancer and changes were variable between different response categories (Rajan et al, 2004). It is unknown whether these changes correlate into a survival advantage. Tumour cellularity changes in the non- 
neoadjuvant setting may be assessed with repeat biopsy at the time of progression, which are increasingly being performed for patients entering clinical trials.

\section{CONCLUSIONS}

From the current study, no evidence exists to use a lower limit of detection beyond what is technically required for EGFR mutation fraction or cellularity to exclude or select EGFR mutation-positive NSCLC patients for EGFR TKI therapy. The presence of EGFR mutant cells in a tumour sample, irrespective of proportion, using a clinical laboratory improvement amendments (CLIA) approved testing method is associated with response in our study. However, it is clear that mutation fraction is associated with outcome, with those patients with higher EGFR mutation fractions having higher response rates, longer time to treatment failure and survival. Therefore, clinicians should be aware of EGFR mutation fraction and consider closer follow-up for patients with lower EGFR mutation fraction. A greater understanding of both primary and secondary resistance is required to identify patients who will not respond to EGFR TKIs. This may allow identification of new treatments and tailoring of these on an individual basis.

\section{ACKNOWLEDGEMENTS}

This study has been funded in part through the University Of Toronto Division Of Medical Oncology Strategic Planning Innovation Fund and the Princess Margaret Cancer Centre Division of Medical Oncology. Astra Zeneca Canada provides funding to the University Health Network Molecular Laboratory for EGFR testing but has not been involved in this study.

\section{CONFLICT OF INTEREST}

The authors declare no conflict of interest.

\section{REFERENCES}

Antonicelli A, Cafarotti S, Indini A, Galli A, Russo A, Cesario A, Lococo FM, Russo P, Mainini AF, Bonifati LG, Nosotti M, Santambrogio L, Margaritora S, Granone PM, Dutly AE (2013) EGFR-targeted therapy for non-small cell lung cancer: focus on EGFR oncogenic mutation. Int J Med Sci 10(3): 320-330.

Cadranel J, Ruppert AM, Beau-Faller M, Wislez M (2013) Therapeutic strategy for advanced EGFR mutant non-small-cell lung carcinoma. Crit Rev Oncol Hematol 88(3): 477-493.

Camidge DR, Kono SA, Flacco A, Tan AC, Doebele RC, Zhou Q, Crino L, Franklin WA, Varella-Garcia M (2010) Optimizing the detection of lung cancer patients harboring anaplastic lymphoma kinase (ALK) gene rearrangements potentially suitable for ALK inhibitor treatment. Clin Cancer Res 16(22): 5581-5590.

Camidge DR, Skokan M, Kiatsimkul P, Helfrich B, Lu X, Baron AE, Schulte N, Maxson D, Aisner DL, Franklin WA, Doebele RC, Varella-Garcia M (2013) Native and rearranged ALK copy number and rearranged cell count in non-small cell lung cancer: implications for ALK inhibitor therapy. Cancer 119: 3968-3975.

Cappuzzo F, Hirsch FR, Rossi E, Bartolini S, Ceresoli GL, Bemis L, Haney J, Witta S, Danenberg K, Domenichini I, Ludovini V, Magrini E, Gregorc V, Doglioni C, Sidoni A, Tonato M, Franklin WA, Crino L, Bunn PA, Varella-Garcia M (2005) Epidermal growth factor receptor gene and protein and gefitinib sensitivity in non-small-cell lung cancer. J Natl Cancer Inst 97(9): 643-655.

Crockford A, Jamal-Hanjani M, Hicks J, Swanton C (2014) Implications of intratumour heterogeneity for treatment stratification. J Pathol 232(2): 264-273.
Ellis LM, Hicklin DJ (2009) Resistance to targeted therapies: refining anticancer therapy in the era of molecular oncology. Clin Cancer Res 15(24): 7471-7478.

Gocke CD, Benko FA, Kopreski MS, Evans DB (2000) Enrichment methods for mutation detection. Ann NY Acad Sci 906: 31-38.

Hammerman PS, Janne PA, Johnson BE (2009) Resistance to epidermal growth factor receptor tyrosine kinase inhibitors in non-small cell lung cancer. Clin Cancer Res 15(24): 7502-7509.

Heinmoller P, Gross C, Beyser K, Schmidtgen C, Maass G, Pedrocchi M, Ruschoff J (2003) HER2 status in non-small cell lung cancer: results from patient screening for enrollment to a phase II study of herceptin. Clin Cancer Res 9(14): 5238-5243.

Hirsch FR, Varella-Garcia M, Franklin WA, Veve R, Chen L, Helfrich B, Zeng C, Baron A, Bunn Jr. PA (2002) Evaluation of HER-2/neu gene amplification and protein expression in non-small cell lung carcinomas. Br J Cancer 86(9): 1449-1456.

Inoue A, Kobayashi K, Maemondo M, Sugawara S, Oizumi S, Isobe H, Gemma A, Harada M, Yoshizawa H, Kinoshita I, Fujita Y, Okinaga S, Hirano H, Yoshimori K, Harada T, Saijo Y, Hagiwara K, Morita S, Nukiwa T (2013) Updated overall survival results from a randomized phase III trial comparing gefitinib with carboplatin-paclitaxel for chemo-naive non-small cell lung cancer with sensitive EGFR gene mutations (NEJ002). Ann Oncol 24(1): 54-59.

Jackman D, Pao W, Riely GJ, Engelman JA, Kris MG, Janne PA, Lynch T, Johnson BE, Miller VA (2010) Clinical definition of acquired resistance to epidermal growth factor receptor tyrosine kinase inhibitors in non-smallcell lung cancer. J Clin Oncol 28(2): 357-360.

Kamel-Reid S, Chong G, Ionescu DN, Magliocco AM, Spatz A, Tsao M, Weng X, Young S, Zhang T, Soulieres D (2012) EGFR tyrosine kinase mutation testing in the treatment of non-small-cell lung cancer. Curr Oncol 19(2): e67-e74.

Kobayashi S, Boggon TJ, Dayaram T, Janne PA, Kocher O, Meyerson M, Johnson BE, Eck MJ, Tenen DG, Halmos B (2005) EGFR mutation and resistance of non-small-cell lung cancer to gefitinib. N Engl J Med 352(8): 786-792.

Korpanty G, Leighl NB (2012) Challenges in NSCLC molecular testing Barriers to implementation. oe 11(4): 8-10.

Lara-Guerra H, Chung CT, Schwock J, Pintilie M, Hwang DM, Leighl NB, Waddell TK, Tsao MS (2012) Histopathological and immunohistochemical features associated with clinical response to neoadjuvant gefitinib therapy in early stage non-small cell lung cancer. Lung Cancer 76(2): 235-241.

Leary AF, Castro DG, Nicholson AG, Ashley S, Wotherspoon A, O'Brien ME, Popat S (2012) Establishing an EGFR mutation screening service for nonsmall cell lung cancer-sample quality criteria and candidate histological predictors. Eur J Cancer 48(1): 61-67.

Lindeman NI, Cagle PT, Beasley MB, Chitale DA, Dacic S, Giaccone G, Jenkins RB, Kwiatkowski DJ, Saldivar JS, Squire J, Thunnissen E, Ladanyi M (2013) Molecular testing guideline for selection of lung cancer patients for EGFR and ALK tyrosine kinase inhibitors: guideline from the College of American Pathologists, International Association for the Study of Lung Cancer, and Association for Molecular Pathology. J Thorac Oncol 8(7): 823-859.

Maemondo M, Inoue A, Kobayashi K, Sugawara S, Oizumi S, Isobe H, Gemma A, Harada M, Yoshizawa H, Kinoshita I, Fujita Y, Okinaga S, Hirano H, Yoshimori K, Harada T, Ogura T, Ando M, Miyazawa H, Tanaka T, Saijo Y, Hagiwara K, Morita S, Nukiwa T (2010) Gefitinib or chemotherapy for non-small-cell lung cancer with mutated EGFR. $N$ Engl J Med 362(25): 2380-2388.

Mayer IA (2009) Treatment of HER2-Positive Metastatic Breast Cancer Following Initial Progression. Clin Breast Cancer 9(Suppl 2): S50-S57.

Milbury CA, Li J, Makrigiorgos GM (2009) PCR-based methods for the enrichment of minority alleles and mutations. Clin Chem 55(4): 632-640.

Mitsudomi T, Morita S, Yatabe Y, Negoro S, Okamoto I, Tsurutani J, Seto T, Satouchi M, Tada H, Hirashima T, Asami K, Katakami N, Takada M, Yoshioka H, Shibata K, Kudoh S, Shimizu E, Saito H, Toyooka S, Nakagawa K, Fukuoka M (2010) Gefitinib versus cisplatin plus docetaxel in patients with non-small-cell lung cancer harbouring mutations of the epidermal growth factor receptor (WJTOG3405): an open label, randomised phase 3 trial. Lancet Oncol 11(2): 121-128.

Mok TS, Wu YL, Thongprasert S, Yang CH, Chu DT, Saijo N, Sunpaweravong P, Han B, Margono B, Ichinose Y, Nishiwaki Y, Ohe Y, Yang JJ, 
Chewaskulyong B, Jiang H, Duffield EL, Watkins CL, Armour AA, Fukuoka M (2009) Gefitinib or carboplatin-paclitaxel in pulmonary adenocarcinoma. N Engl J Med 361(10): 947-957.

Pao W, Miller VA, Politi KA, Riely GJ, Somwar R, Zakowski MF, Kris MG, Varmus H (2005) Acquired resistance of lung adenocarcinomas to gefitinib or erlotinib is associated with a second mutation in the EGFR kinase domain. PLoS Med 2(3): e73.

Rajan R, Poniecka A, Smith TL, Yang Y, Frye D, Pusztai L, Fiterman DJ, Gal-Gombos E, Whitman G, Rouzier R, Green M, Kuerer H, Buzdar AU, Hortobagyi GN, Symmans WF (2004) Change in tumor cellularity of breast carcinoma after neoadjuvant chemotherapy as a variable in the pathologic assessment of response. Cancer 100(7): 1365-1373.

Rosell R, Carcereny E, Gervais R, Vergnenegre A, Massuti B, Felip E, Palmero R, Garcia-Gomez R, Pallares C, Sanchez JM, Porta R, Cobo M, Garrido P, Longo F, Moran T, Insa A, De Marinis F, Corre R, Bover I, Illiano A, Dansin E, de Castro J, Milella M, Reguart N, Altavilla G, Jimenez U, Provencio M, Moreno MA, Terrasa J, Munoz-Langa J, Valdivia J, Isla D, Domine M, Molinier O, Mazieres J, Baize N, Garcia-Campelo R, Robinet G, Rodriguez-Abreu D, Lopez-Vivanco G, Gebbia V, Ferrera-Delgado L, Bombaron P, Bernabe R, Bearz A, Artal A, Cortesi E, Rolfo C, SanchezRonco M, Drozdowskyj A, Queralt C, de Aguirre I, Ramirez JL, Sanchez JJ, Molina MA, Taron M, Paz-Ares L (2012) Erlotinib versus standard chemotherapy as first-line treatment for European patients with advanced EGFR mutation-positive non-small-cell lung cancer (EURTAC): a multicentre, open-label, randomised phase 3 trial. Lancet Oncol 13(3): 239-246.

Rosell R, Moran T, Queralt C, Porta R, Cardenal F, Camps C, Majem M, Lopez-Vivanco G, Isla D, Provencio M, Insa A, Massuti B, GonzalezLarriba JL, Paz-Ares L, Bover I, Garcia-Campelo R, Moreno MA, Catot S, Rolfo C, Reguart N, Palmero R, Sanchez JM, Bastus R, Mayo C, Bertran-Alamillo J, Molina MA, Sanchez JJ, Taron M (2009) Screening for epidermal growth factor receptor mutations in lung cancer. N Engl J Med 361(10): 958-967.

Sequist LV, Martins RG, Spigel D, Grunberg SM, Spira A, Janne PA, Joshi VA, McCollum D, Evans TL, Muzikansky A, Kuhlmann GL, Han M, Goldberg JS, Settleman J, Iafrate AJ, Engelman JA, Haber DA, Johnson BE, Lynch TJ (2008) First-line gefitinib in patients with advanced non-small-cell lung cancer harboring somatic EGFR mutations. J Clin Oncol 26(15): 24422449.

Sequist LV, Waltman BA, Dias-Santagata D, Digumarthy S, Turke AB, Fidias P, Bergethon K, Shaw AT, Gettinger S, Cosper AK, Akhavanfard S, Heist RS, Temel J, Christensen JG, Wain JC, Lynch TJ, Vernovsky K, Mark EJ, Lanuti M, Iafrate AJ, Mino-Kenudson M, Engelman JA (2011) Genotypic and histological evolution of lung cancers acquiring resistance to EGFR inhibitors. Sci Transl Med 3(75): 75ra26.

Shan L, Wang Z, Guo L, Sun H, Qiu T, Ling Y, Li W, Li L, Liu X, Zheng B, Lu N, Ying J (2015) Concurrence of EGFR amplification and sensitizing mutations indicate a better survival benefit from EGFR-TKI therapy in lung adenocarcinoma patients. Lung Cancer 89(3): 337-342.
Shiau CJ, Babwah JP, da Cunha Santos G, Sykes JR, Boerner SL, Geddie WR, Leighl NB, Wei C, Kamel-Reid S, Hwang DM, Tsao MS (2014) Sample features associated with success rates in population-based EGFR mutation testing. J Thorac Oncol 9(7): 947-956.

Snuderl M, Fazlollahi L, Le LP, Nitta M, Zhelyazkova BH, Davidson CJ, Akhavanfard S, Cahill DP, Aldape KD, Betensky RA, Louis DN, Iafrate AJ (2011) Mosaic amplification of multiple receptor tyrosine kinase genes in glioblastoma. Cancer Cell 20(6): 810-817.

Sottoriva A, Spiteri I, Piccirillo SG, Touloumis A, Collins VP, Marioni JC, Curtis C, Watts C, Tavare S (2013) Intratumor heterogeneity in human glioblastoma reflects cancer evolutionary dynamics. Proc Natl Acad Sci USA 110(10): 4009-4014.

Swanton C (2012) Intratumor heterogeneity: evolution through space and time. Cancer Res 72(19): 4875-4882.

Taniguchi K, Okami J, Kodama K, Higashiyama M, Kato K (2008) Intratumor heterogeneity of epidermal growth factor receptor mutations in lung cancer and its correlation to the response to gefitinib. Cancer Sci 99(5): 929-935.

Turke AB, Zejnullahu K, Wu YL, Song Y, Dias-Santagata D, Lifshits E, Toschi L, Rogers A, Mok T, Sequist L, Lindeman NI, Murphy C, Akhavanfard S, Yeap BY, Xiao Y, Capelletti M, Iafrate AJ, Lee C, Christensen JG, Engelman JA, Janne PA (2010) Preexistence and clonal selection of MET amplification in EGFR mutant NSCLC. Cancer Cell 17(1): 77-88.

Vogelstein B, Papadopoulos N, Velculescu VE, Zhou S, Diaz LA, Kinzler KW (2013) Cancer Genome Landscapes. Science 339(6127): 1546-1558.

Yang JCH, Schuler M, Yamamoto N, O'Byrne KJ, Hirsch V, Mok TS, Geater SL, Orlov SV, Tsai C-M, Boyer MJ, Su WC, Bennouna J, Kato T, Gorbunova VA, Lee KH, Shah RNH, Massey D, Lorence RM, Shahidi M, Sequist LV (2012) LUX-Lung 3: a randomized, open-label, phase III study of afatinib versus pemetrexed and cisplatin as first-line treatment for patients with advanced adenocarcinoma of the lung harboring EGFRactivating mutations. J Clin Oncol 30(suppl): LBA7500.

Yu HA, Arcila ME, Hellmann MD, Kris MG, Ladanyi M, Riely GJ (2014) Poor response to erlotinib in patients with tumors containing baseline EGFR T790M mutations found by routine clinical molecular testing. Ann Oncol 25(2): 423-428.

Zhou C, Wu YL, Chen G, Feng J, Liu XQ, Wang C, Zhang S, Wang J, Zhou S, Ren S, Lu S, Zhang L, Hu C, Luo Y, Chen L, Ye M, Huang J, Zhi X, Zhang Y, Xiu Q, Ma J, You C (2011) Erlotinib versus chemotherapy as first-line treatment for patients with advanced EGFR mutation-positive non-smallcell lung cancer (OPTIMAL, CTONG-0802): a multicentre, open-label, randomised, phase 3 study. Lancet Oncol 12(8): 735-742.

This work is published under the standard license to publish agreement. After 12 months the work will become freely available and the license terms will switch to a Creative Commons AttributionNonCommercial-Share Alike 4.0 Unported License. 